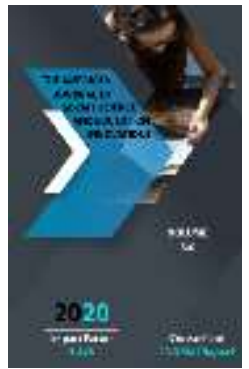

\section{Literary Relations Between Uzbekistan And Germany}

\author{
Sodirjon Yakubov \\ Candidate Of Philological Sciences, Senior Lecturer, Department Of “World Literature", \\ Faculty Of Foreign Philology, National University Of Uzbekistan Named After Mirzo Ulugbek, \\ Uzbekistan
}

Journal Website: http://usajournalshub.c om/index,php/tajssei

Copyright: Original content from this work may be used under the terms of the creative commons attributes 4.0 licence.

\title{
ABSTRACT
}

From the ancient, philosophical epics of the East, to the works of people who are built on conflicting opinions and who can fight for their happiness in the face of adversity, the German people love to read. The friendship of these literatures is a unique symbol of the friendship of peoples.

\section{KEYWORDS}

Oriental, philosophical epic, tradition, friendship of literature, friendship of peoples, art of translation, school of translation.

\section{INTRODUCTION}

Friendly creative ties in German-Uzbek literature have made a significant contribution not only to the development of Uzbek and German literature, but also to the enrichment of world literature. The fruitful work and scientific research of literary critics have provided not only the development of scientific and literary theory, but also many readable literatures for Uzbek and German readers. Since the importance of literature in the education of human thought is incomparable, the deeply meaningful works of writers have contributed to the rise of the culture of nations. 


\section{THE MAIN FINDINGS AND RESULTS}

From scholars of literature, fine arts, decoration, architecture and other cultures to ordinary intellectuals, everyone has always been interested in the books of Uzbek classics, and later in the works of our modern writers imbued with humanistic ideas. European readers are still built on contradictory considerations, ranging from the ancient, philosophical epics of the East. Even our prose works about the fate of people who can fight for their happiness in spite of hardships are loved and read by all. Because they, too, find similarities by reading the lifestyles, feelings and experiences of artistic images in the literature of other nations, their struggles against injustice. Understands the historical errors of national conflicts, gets closer spiritually with different ethnic groups.

Therefore, as long as there are social issues and contradictions in society, the development of inter-ethnic literature will continue, and one of the main tasks of Uzbek writers will be to cover issues in an artistic way.

Uzbek-German literary relations are enduring. As the President said: "We have objectively assessed the current state of Uzbek-German relations and identified priorities and tasks for their further development".

There are still many undiscovered, unexplored aspects of German literature. There are also many unsolved mysteries of Oriental literature for Germany. Therefore, writers of both countries will continue to develop creative ties, our translators will continue to translate works from German into Uzbek, and German experts will continue to translate works from
Uzbek into German. Literature always unites these two peoples, despite the fact that the West and the East, Germany and Uzbekistan, different nationalities, different religions, as well as different traditions, cultures and worldviews. The regular continuation of their research in literature will enrich the literature of both nations; serve the development of their cultures, the well-being of the peoples. Works of Uzbek writers have been translated into various languages. Many foreign literary scholars still translate the history of Uzbek literature with greater sincerity. In prestigious libraries and museums, as well as our historical manuscripts, the printed books of our modern works are treasured. Our books, which are highly published in our printing houses, are valued by Europeans as a work of art.

The German people have a great interest in the life and way of life of the Uzbek people, in classical literature, history, ancient architecture and crafts, fine arts, in short, in Uzbek culture. Therefore, they strive to strengthen friendly relations in all areas.

In literature, "Childhood" by Oybek, "Sisters" by Askad Mukhtor, "Fate" by Ibrahim Rahim, "Crane" by Said Ahmad, "New Neighbors" Hakim Nazir, poet Zulfiya's poems, Khudoiberdi Tukhtaboyev's children's favorite works have passed through various passages in the literature and skillfully translated the best stories and short stories of Utkir Hoshimov and the works of other writers into German. German readers like the elegance of Uzbek literature, the richness of ordinary human emotions, the vivid expression of events, and enjoy the oriental spirit.

The work of German translators is also to be commended. Due to their creative research, Uzbek literature became popular in Germany 
and in neighboring countries where German is spoken.

Our literature, which has emerged on the basis of Turkic and other languages over the centuries, has crossed the highest passes despite historical difficulties. Although Uzbek literature has suffered in political crises, it has retained its psyche. The works of Uzbek writers have become masterpieces of world culture. The most important event is the fact that our writers have friendly relations with European as well as German writers.

Uzbek readers also enjoy German literature. They read in Uzbek the complex, philosophical works of the greatest poets and writers of Germany. The pen of our translators was sharpened, and Uzbek Translation School was established.

Friendly creative ties in Uzbek-German literature also contribute to the development of Uzbek-German political and economic relations. Where mutual trust is strong, people who are aware of the arts and culture of the two countries will always strive to work together. As the President of our country noted, "Cooperation between Uzbekistan and Germany in the fields of science, culture, education and healthcare is developing rapidly. There is a growing interest in the German language and culture in our country. Your "Schools: Prospective Partners" initiative is being successfully implemented. Currently, more than 400,000 students study German in Uzbekistan, which is the language of Kant, Gegel and Schiller. The total number of German-language schools in our country is about 1,700. Over the past year, more than 400 new German language classes have been opened".

"... Our agreements and agreements signed in Berlin are being consistently implemented today. In particular, projects in the field of high technology, industry and agriculture, energy, transport and logistics, infrastructure are being implemented in Uzbekistan together with major German companies such as "Siemens», «The Linde Group», «Thyssen», «Volkswagen», «MAN», «CLAAS», «LEMKEN», «Knauf», «Deutsche Kabel», and «Oberhofer». During the state visit of President Shavkat Mirziyoev to the Federal Republic of Germany, open and transparent talks were held between the two countries to further expand our wide-ranging cooperation in the political, economic, scientific, educational, cultural and educational spheres. This historic visit also set priorities and tasks for the expansion of comprehensive ties between the two countries and peoples, in particular, for the skillful translation of works by Uzbek-German writers. The results of the high-level talks will open new opportunities in Uzbek-German relations.

The literature of these two countries has been the main tool in the closeness of the two countries, the strengthening of ties, the strengthening of friendship between the peoples, namely:

- The emergence and development of modern Uzbek-German literature, as well as the interaction of art and culture is rooted in history and has its own history.

- The history of Uzbek-German literary relations can be divided into several periods: the ancient period - the period of the flourishing of ancient classical literature in the East and the period of modern Uzbek literature - the period of works of art in modern prose. Studying in such periods is a relief not only for those who are engaged in science, but also for ordinary readers. 
- Our people have had the opportunity to read in Uzbek the works of various German writers, from the philosophical works of the great Goethe to the democratic writer of our time Anna Zegers.

- "The translation into German of the works of our classical literature, from the great poet and thinker Alisher Navoi to prose writers and masters of words Abdulla Kodiri and Abdulla Kahhor, has made a significant contribution to the development of German literature.

- As a result of scientific research on Uzbek literature by German literary scholars, the German people recognized the names of many Uzbek writers, became more and more acquainted with the information about their creative activities and works.

- As a result of conferences, days of culture and other events held by the Writers 'Union of Uzbekistan and the German Writers' Union, the ties of friendship between the two peoples has been strengthened. The two countries got acquainted with each other's traditions, way of life, culture, art, history, nature, ancient cities.

\section{CONCLUSION}

We hope that the friendship between the two countries will continue to be stable. As President Shavkat Mirziyoev said at the official meeting with the President of Germany, "I am convinced that the opening of the statue of the great German poet and thinker Goethe in Tashkent will become a new symbol of friendship and cooperation between our peoples ...

We attach great importance to developing long-term and multifaceted relations with Germany, maintaining a high level of communication based on mutual trust. I am confident that the results of today's talks will open new horizons in Uzbek-German relations".

Indeed, literature has led to a strong friendship, which has laid the foundation for a creative environment, the writing of new works, the solution of social problems, and even the development of political and economic ties.

\section{REFERENCES}

1. Shavkat Mirziyoev. (2019) Uzbekistan and Germany: High-level dialogue based on mutual trust. Selected works. Volume IV. Tashkent, Uzbekistan Publishing House. Volume III. - pp. 311-314.

2. Shavkat Mirziyoev. (2019) Uzbekistan and Germany are reliable, important and longterm partners. Selected works. Volume IV. Tashkent, Uzbekistan Publishing House. Volume III. - pp. 315-319.

3. Konrad N.I. (1972) West and East. Ed. Eastern literature. - Moscow.

4. Konrad N.I. (1972) West and East. (Articles). - Moscow.

5. Lomidze G.N. (1960) Problems of creative interaction of the literatures of the peoples of the USSR. - Moscow.

6. Neupokoeva I.G. (1963) Problems of the interaction of modern literatures. Moscow. Editorial. Academy of Sciences of the USSR.

7. Neupokoeva I.G. (1960) Some questions of the study of the relationship and interaction of national literatures. Moscow.

8. Rashidov Sh. (1967) The banner of friendship. - Moscow: «Politizdat».

9. Salomov G.N. (1966) Language and translation. - Tashkent: «Fan». 
10. The art of translation. - Tashkent, 1978.

11. Topical issues of literary translation. Tashkent, 1977.
12. Sharipov J.T. (1959) Some issues of poetic translation. - Tashkent: «Fan». 